\title{
HUBUNGAN PELAKSANAAN PRAKTIK KERJA INDUSTRI TERHADAP KESIAPAN MEMASUKI DUNIA KERJA PADA KOMPETENSI KEAHLIAN TEKNIK KENDARAAN RIGAN SISWA KELAS XI Di SMK NEGERI 2 LUBUK BASUNG
}

\author{
Nurul Amal', Martias ${ }^{2}$, Dwi Sudarno Putra ${ }^{3}$ \\ 1,2,3 Jurusan Teknik Otomotif FT UNP, Fakultas Teknik, Universitas Negeri Padang \\ 1nurulama154@gmail.com, ${ }^{2}$ martiasft@gmail.com, ${ }^{3}$ dwisudarnoputra@gmail.com
}

\begin{abstract}
Abstrak
Penelitian ini dilatar belakangi oleh sedikitnya tamatan yang diterima untuk bekerja di dunia usaha atau dunia industri. Populasi pada penelitian ini adalah siswa kelas XI kompetensi keahlian Teknik Kendaraan Ringan berjumlah 81 orang dan 5 orang guru pembimbing. Teknik penarikan sampel adalah sample random sampling. Sampel penelitian ini berjumlah 45 orang siswa dan seluruh guru pembimbing yaitu 5 orang. Alat pengumpulan data adalah angket yang telah di validitasi. Hasil penelitian menunjukkan bahwa praktik kerja industri berhubungan positif dan signifikan terhadap kesiapan memasuki dunia kerja dengan nilai korelasi 0,227 dan nilai signifikansi 0,046 . Hal ini berarti bahwa secara parsial praktik kerja industri mempunyai hubungan yang signifikan terhadap kesiapan memasuki dunia kerja siswa kelas XI kompetensi keahlian Teknik Kendaraan Ringan SMK Negeri 2 Lubuk Basung.
\end{abstract}

Kata Kunci: Siswa, Praktik, Kerja, Industri, Kesiapan Kerja

\begin{abstract}
This research is based on at least graduates who are accepted to work in the business world or industrial world. The population in this study are students of class XI competence of Light Vehicle Engineering expertise amounted to 81 people and 5 teachers of mentors. Sampling technique is sample random sampling. The sample of this study amounted to 45 students and all mentoring teachers were 5 people. The data collection tool is a validated questionnaire. The results showed that industry work practices were positively and significantly related to the readiness to enter the workforce with a correlation value of 0.227 and a significance value of 0.046 . This means that partially industrial work practices have a significant relationship to the readiness to enter the workforce of students of class XI competence in the expertise of Light Vehicle Engineering SMK Negeri 2 Lubuk Basung.
\end{abstract}

Keywords: Student, Practice, Work, Industry, Readiness Work

Received date 1/12/2019, Revised date 22/12/2019, Accepted date 07/01/2020 


\section{PENDAhULUAN}

Perkembangan pembangunan Indonesia dewasa ini semakin pesat di segala bidang dengan tujuan meningkatkan kesejahteraan seluruh masyarakat. Bidang teknologi dan industri merupakan yang paling cepat berkembang, sehingga menuntut masyarakat untuk menjadi tenaga kerja yang terampil dan memiliki keahlian serta kepribadian pekerja keras. Tenaga kerja yang kompeten di bidang tersebut diharapkan mampu menciptakan lapangan kerja baru atau memperluas cakupan lapangan kerja disamping melaksanakan tugas-tugas dalam pekerjaannya.

Pembangunan yang dilakukan tanpa tenaga kerja yang ahli dan terampil akan menyebabkan proses kerja kurang produktif dan kurang efisien. Dalam hal ini terjadinya hambatan selama proses pekerjaan berlangsung sehingga hasil dari pekerjaan menjadi kurang bermutu. Dunia pendidikan sekarang tidak terlepas dari keterkaitan dengan dunia industri. Hal ini dibuktikan dengan banyaknya dunia industri menerima lulusan lembaga pendidikan formal dibandingkan lembaga pendidikan non formal sebagai tenaga kerja sesuai bidang pendidikannya.

Sekolah Menengah Kejuruan (SMK) merupakan salah satu lembaga pendidikan formal dengan harapan dapat menghasilkan lulusan yang terampil dan siap untuk terjun langsung ke dunia usaha atau dunia industri [1]. Sekolah Menengah Kejuruan (SMK) memiliki peranan yang sangat penting dalam sistem pendidikan yang berfungsi menyiapkan tenaga kerja yang terampil sesuai dengan keahlian tertentu. Undang-Undang Sistem Pendidikan Nasional No. 20 tahun 2003 Pasal 15, menyatakan pendidikan kejuruan merupakan pendidikan menengah yang mempersiapkan peserta didik terutama untuk bekerja dalam bidang tertentu.

Pendidikan kejuruan bertujuan mempersiapkan peserta didik untuk mampu memasuki lapangan kerja, dapat mengembangkan diri dalam pekerjaan dan dapat menjadi tenaga kerja yang professional. Kesiapan kerja adalah keseluruhan kondisi individu yang meliputi kematangan fisik, mental dan pengalaman sehingga mampu untuk melakukan suatu kegiatan atau pekerjaan [2]. 
Tabel 1. Kegiatan Alumni SMK Negeri 2 Lubuk Basung Tamatan Tahun 2017

\begin{tabular}{|c|c|c|}
\hline Kegiatan & Jumlah & Persentase \\
\hline Perguruan Tinggi Negeri & 23 orang & $6.79 \%$ \\
\hline Perguruan Tinggi Swasta & 16 orang & $4.70 \%$ \\
\hline Dunia Usaha & 14 orang & $4.10 \%$ \\
\hline Dunia Industri & 4 orang & $1.18 \%$ \\
\hline Tanpa Keterangan & 282 orang & $83.19 \%$ \\
\hline Total & $\mathbf{3 3 9}$ orang & $\mathbf{1 0 0} \%$ \\
\hline
\end{tabular}

Sumber : Tata Usaha SMK Negeri 2 Lubuk Basung 2018

Dari tabel 1 diketahui bahwa sangat sedikit tamatan yang diterima untuk bekerja di dunia usaha atau dunia industri yakni sebesar $5.28 \%$. Dari data yang penulis dapatkan, hanya 5 orang tamatan kompetensi keahlian Teknik Kendaraan Ringan yang diterima di dunia usaha atau dunia industri. Dari tabel tersebut terlihat cukup banyak tamatan tanpa keterangan yakni sebesar $83.19 \%$. Dalam pelaksanaan prakerin sekarang waktu yang ditetapkan selama 3 bulan. Dari wawancara kepada siswa mereka mengatakan belum puas dengan waktu pelaksanaan 3 bulan karena bagi mereka pada bulan pertama memasuki dunia industri banyak dilakukan hanya untuk beradaptasi. Sedangkan pada bulan terakir mereka baru merasakan dunia kerja yang sesungguhnya. Hal ini menyebabkan siswa belum siap memasuki dunia kerja karena keterbatasan pengalaman dan ilmu yang mereka dapatkan selama pelaksanaan prakerin.

Selama pelaksanaan prakerin dari segi mentoring juga belum terlaksana sepenuhnya. Berdasarkan observasi yang dilakukan, guru pembimbing jarang memantau perkembangan siswa bimbingannya. Setidaknya guru pembimbing hanya melakukan sekali pemantauan terhadap siswanya. Hal ini dapat menghambat siswa untuk berkonsultasi mengenai kegiatan yang dilakukan di tempat mereka melaksanakan prakerin. Dapat disimpulkan bahwa pelaksanaan praktik kerja industri belum sepenuhnya terlaksana dengan baik. Hal ini menyebabkan kurang maksimalnya kemampuan siswa dalam melaksanakan pekerjaan yang berakibat kurangnya kesiapan siswa untuk memasuki dunia kerja. 
Dari permasalahan tersebut penulis tertarik untuk melakukan penelitian yang berjudul "Hubungan Pelaksanaan Praktik Kerja Industri (Prakerin) terhadap Kesiapan Memasuki Dunia Kerja Bagi Siswa Kelas XI Kompetensi Keahlian Teknik Kendaraan Ringan SMK Negeri 2 Lubuk Basung”. Adapun tujuan penelitian ini adalah untuk mendapatkan informasi tentang hubungan pelaksanaan praktik kerja industri (prakerin) terhadap kesiapan memasuki dunia kerja bagi siswa kelas XI kompetensi keahlian Teknik Kendaraan Ringan SMK Negeri 2 Lubuk Basung.

\section{METODA}

Jenis penelitian yang dilakukan adalah penelitian deskriptif dan asosiatif. Penelitian deskriptif merupakan penelitian yang dimaksudkan untuk mengumpulkan informasi mengenai status suatu gejala yang ada, yaitu keadaan gejala menurut apa adanya pada saat penelitian dilakukan, sedangkan penelitian asosiatif adalah penelitian yang menguji ada atau tidaknya hubungan atau pengaruh antara satu variabel dengan variabel lainnya [3-4].

Populasi yang diambil adalah siswa kelas XI kompetensi keahlian Teknik Kendaraan Ringan SMK Negeri 2 Lubuk Basung tahun ajaran 2017/2018 yang berjumlah 81 siswa yang terdiri dari XI TKR 1,2,3 dan populasi guru pembimbing prakerin berjumlah 5 orang. Jumlah sampel siswa yang diambil yaitu 45 orang dan guru pembimbing berjumlah 5 orang. Teknik penarikan sampel yang digunakan adalah sample random sampling, yaitu teknik untuk mendapatkan sampel yang dilakukan secara acak.

Alat pengumpulan data dalam penelitian ini adalah melalui angket (kuesioner). Angket (kuesioner) merupakan suatu pengumpulan data dengan memberikan atau menyebarkan daftar pertanyaan/pernyataan kepada responden dengan harapan memberikan respons atas daftar pertanyaan tersebut.

\section{HASIL DAN PEMBAHASAN}

Memasuki dunia kerja menjadi salah satu tujuan bagi mereka yang sudah memiliki bekal dan kesiapan diri setelah pelaksanaan praktik kerja industri. Hal 
ini juga tidak terlepas dari dukungan pihak sekolah dan motivasi dari guru melalui pembelajaran setelah mereka kembali ke sekolah. Dengan memberikan motivasi siswa akan lebih percaya diri untuk mencapai tujuan setelah lulus nanti terutama yang berkaitan dengan dunia kerja. Kesiapan adalah kemampuan yang cukup baik fisik dan mental. Kesiapan fisik berarti tenaga yang cukup dan kesehatan yang baik, sementara kesiapan mental, memiliki minat dan motivasi yang cukup untuk melakukan suatu kegiatan [5]. Kesiapan adalah kesediaan untuk memberi response atau bereaksi. Kesediaan itu timbul dalam diri seseorang dan juga berhubungan dengan kematangan, karena kematangan berarti kesiapan untuk melaksanakan kecakapan.

Kesiapan kerja peserta didik dapat diartikan sebagai suatu kondisi yang menunjukkan adanya keserasian antara kematangan fisik, mental, serta pengalaman sehingga peserta didik mempunyai kemampuan untuk melaksanakan suatu kegiatan tertentu dalam hubungannya dengan pekerjaan atau kegiatan. Di Sekolah Menengah Kejuruan (SMK) kegiatan praktik kerja industri (prakerin) merupakan salah satu program pendidikan sistem ganda yang harus dilakukan oleh sekolah. Praktik industri adalah kegiatan yang dilakukan oleh peserta didik berupa praktik langsung pada dunia kerja yang nyata [6]. Waktu untuk praktik industri beraneka-ragam, ada sekolah yang melakukan dua tiga bulan, ada satu atau dua semester, tergantung dari kebutuhannya. The didactic center of the path of vocational training is the mastery of life at work", dan hal ini hanya bisa dilakukan melalui praktik industri. Tanpa melakukan kegiatan praktik industri secara sistematis, jelas suatu lembaga pendidikan kejuruan tidak akan bisa membekali lulusannya dengan kemampuan kerja yang optimal.

Kemampuan kerja yang optimal bagi peserta praktik kerja industri akan didapatkan melalui bimbingan secara memadai di dunia industri. Hal ini tentu dengan adanya kerjasama yang optimal antara pihak sekolah dan dunia usaha atau dunia industri. Untuk menghindari kegagalan dalam pelaksanaan prakerin ini, maka kedua pihak harus saling memahami peran dan tanggungjawab masing-masing agar tujuan dapat tercapai. Secara garis besar pihak industri/instruktur industri berperan dalam hal merencanakan segala kebutuhan 
yang diperlukan oleh siswa selama mengadakan praktik di industri, memberi bimbingan pada siswa dalam kegiatan pembelajaran praktik di industri, mengevaluasi kemajuan belajar praktik siswa, mengadakan hubungan dengan pihak sekolah berkaitan dengan segala kegiatan pembelajaran siswa.

Untuk mempermudah selama kegiatan belajar praktik, siswa harus memilki lembar kerja [7]. Menyiapkan lembar kerja praktik merupakan tugas dan kewajiban instruktur yang sangat penting. Mengingat kedatangan siswa ke industri masih dalam konteks belajar, maka kegiatan belajar praktik siswa harus betul-betul mendapatkan bimbingan secara maksimal dari para instruktur. Dalam penelitian ini ada dua variabel yang digunakan yaitu praktik kerja industri (X) sebagai variabel bebas dan kesiapan memasuki dunia kerja (Y) sebagai variabel terikat.

Berdasarkan hasil pengujian hipotesis dapat diketahui bahwa praktik kerja industri mempunyai hubungan yang signifikan terhadap kesiapan memasuki dunia kerja bagi siswa kelas XI kompetensi keahlian Teknik Kendaraan Ringan SMK Negeri 2 Lubuk Basung. Praktik kerja industri berhubungan positif terhadap kesiapan memasuki dunia kerja dengan nilai korelasi 0,227 dan signifikansi sebesar 0,046. Hal ini dapat diartikan bahwa baik buruknya hubungan pelaksanaan praktik kerja industri dapat menentukan sejauhmana kesiapan memasuki dunia kerja bagi siswa kelas XI kompetensi keahlian Teknik Kendaraan Ringan SMK Negeri 2 Lubuk Basung.

Penelitian ini sejalan dengan penelitian yang telah dilakukan sebelumnya bahwa variabel pengalaman afektif Praktik Kerja Industri memberi kontribusi yang cukup signifikan terhadap kesiapan siswa memasuki dunia kerja.

\section{SIMPULAN DAN SARAN}

Berdasarkan penelitian yang penulis lakukan maka dapat ditarik kesimpulan bahwa terdapat hubungan antara praktik kerja industri terhadap kesiapan memasuki dunia kerja dengan nilai korelasi 0,227 dan nilai signifikansi 0,046. Hal ini berarti bahwa secara parsial praktik kerja industri mempunyai hubungan yang signifikan terhadap kesiapan memasuki dunia kerja siswa kelas XI kompetensi 
keahlian Teknik Kendaraan Ringan SMK Negeri 2 Lubuk Basung. Dengan demikian semakin baik praktik kerja industri maka akan semakin baik kesiapan memasuki dunia kerja bagi siswa kelas XI kompetensi keahlian Teknik Kendaraan Ringan SMK Negeri 2 Lubuk Basung.

Berdasarkan hasil penelitian di atas penulis menyarankan: pertama, siswa diharapkan lebih giat belajar terutama pada mata pelajaran kejuruan agar praktik kerja industri dapat dilaksanakan dengan baik dan siswa diharapkan dapat meningkatkan kerjasama dengan industri saat pelaksanaan prakerin sehingga siswa lebih siap untuk memasuki dunia kerja. Kedua, sekolah diharapkan menambah waktu pelaksanaan prakerin lebih dari 3 bulan sehingga siswa lebih puas dan lebih siap untuk memasuki dunia kerja, dan guru pembimbing diharapkan untuk melakukan monitoring secara berkala. Ketiga, bagi dunia usaha atau dunia industri agar dapat memberikan bimbingan dan kesempatan kerja yang lebih banyak kepada peserta prakerin serta membuka diri sebagai tempat pelaksanaan prakerin bagi ssiwa khususnya sekolah kejuruan sehingga dapat membantu menghasilkan tamatan yang berkompeten. Keempat, pemerintah diharapkan agar lebih mengutamakan tamatan SMK daripada tamatan SMA untuk dapat bekerja langsung di dunia usaha atau dunia industri karena tamatan SMK telah memiliki kemampuan dan pengalaman kerja yang cukup untuk bekerja.

\section{REFERENSI}

[1] Wena, Made, Pendidikan Sistem Ganda, Bandung : Tarsito, 1996.

[2] Sya'diyah, Nurul Kholifatus, Pengaruh Pengalaman Praktik Kerja Industri (Prakerin) Terhadap Kesiapan Kerja Peserta Didik Program Keahlian Administrasi Perkantoran di SMK Taruna Jaya Gresik, Fakultas Ekonomi : Uniersitas Negeri Surabaya, 2014.

[3] Arikunto, Suharsimi, Manajemen Penelitian, Jakarta : Rineka Cipta, 2010.

[4] Umar, Husein, Metode Penelitian Untuk Skripsi dan Tesis Bisnis, Jakarta : Rajawali Pers, 2011.

[5] Saputro, Andi Haji, Kontribusi Minat Kerja dan Kemampuan Akademis Terhadap Kesiapan Memasuki Dunia Kerja Siswa Kelas XI SMKN 2 Pengasih Kompetensi Keahlian Teknik Gambar Bangunan, FT : UNY, 2013. 
[6] Rahman, Andrey, Maksum Hasan, Putra, Dwi Sudarno, "Kontribusi Pengalaman Afektif Praktik Kerja Industri Terhadap Kesiapan Siswa Memasuki Dunia Kerja Kelas XII Jurusan Teknik Kendaraan Ringan di SMK N 1 Tilatang Kamang”, Automotive Engineering Education Journals, vol. 1, no. 2, pp. 1, 2018.

[7] Anoraga, Panji, Psikologi Kerja, Jakarta : Rineka Cipta, 2009. 